\title{
The Unexpected Volunteer
}

Henry Bair, BS

In this narrative account, the author, a medical student, describes his encounters with several inpatients at a community hospital. He becomes acquainted with a patient's son, who, initially withdrawn, over the course of his mother's hospitalizations transforms into a compassionate volunteer. This change is made especially evident when the author meets another patient who recognizes the volunteer and reveals his very different past. (J Am Board Fam Med 2020;33:481-483.)

Keywords: Community Hospitals, Empathy, Inpatients, Medical Students, Volunteers

It was clear Carl was not used to being confined, not the sort of person who liked to hold still for more than a few seconds if he could help it. Recently, however, he'd been fighting bouts of pneumonia, likely a complication of his chronic bronchitis. He had no choice but to accept when his body needed to rest, which was more and more often, especially after the intensive treatments he was receiving. This was a community hospital, light on the top-tier amenities offered by better-funded facilities and lacking in volunteers to ease patients' time. I was one of the very few medical students clerking here.

While I went to check in on him, he would lament about how useless he felt lying in this bed, how his family needed him, how he had never missed more than 2 days in a row at the convenience store he owned, where his wife and 2 sons were now running things.

"They know what they're doing," he told me, "but no one knows that place like I do. I need to get better so I can get back there. It's too much for them to handle, just the 3 of them."

He was troubled by this. And also bored. He never had any visitors, while I was there, anyway, and I figured this was because his family was

\footnotetext{
This article was externally peer reviewed.

Submitted 19 August 2019; revised 25 September 2019; accepted 18 November 2019.

From Stanford University School of Medicine, Stanford, CA.

Funding: No financial support was received for this submission.

Conflict of interest: The author does not have any conflicts of interest with the subject matter in the manuscript.

Corresponding author: Henry Bair, BS, 291 Campus Drive, Stanford, CA, 94305 (E-mail: hbair@stanford.edu).
}

preoccupied with keeping the business going. As the days passed, I could see his spirits sag, the frustration build. Everything turned into a complaint. The bed was uncomfortable. None of the food tasted good. The water was plain-he only drank seltzer.

"I don't think we have any seltzer here," I said.

"Lime seltzer," he continued, as if he hadn't heard me. "A nice cold can of lime seltzer. That's not asking for too much, is it?"

"It is not. I'll see what we can do."

Carl sighed. "I swear, time slows when you're stuck in a bed like this."

Out of the corner of my eye, I saw Andre, our most recent volunteer, strolling past the doorway. "Hold on," I said to Carl. "I'll be right back."

I hurried out and invited Andre to meet Carl.

He was a few jaunty steps behind me as we returned to Carl's room. I hoped some friendly company might ease his tedium.

Carl had a curious look on his face. Andre appeared a second later, wearing a smile that abruptly disappeared when he saw the patient. Carl's expression turned to one of anger, his eyes blazing.

"Is this some sort of joke?" he exclaimed, looking at me. "Get that kid out of here! What's the meaning of this? Did you find out where I am and come to harass me?" He was interrupted by a paroxysm of coughs.

Andre's mouth fell open and he stuttered a few incoherent words. He quickly backed out of the room.

Carl's eyes widened as he turned to me. "You people don't vet your volunteers?" 
"There's a process," I stuttered. "Do you. . .do you know Andre?"

"Of course I know him. He and his hoodlum punks used to always come into the store and shoplift. I'd recognize that kid anywhere. Now you're telling me he's a volunteer here?"

"Becoming a volunteer here has really helped him," I said. "He's still young. We all make mistakes when we're young."

Carl gave me a level stare. "He cannot be more than a couple of years younger than you. Were you out committing petty theft a few years ago?"

"No."

"Of course you weren't. People don't change. Especially people like that."

I'd first met Andre a few months before Carl's arrival, when he came to the hospital to visit his mother. It had been Sharon's second admission for heart failure, which was stubbornly resisting multiple treatments. Despite her illness, Sharon was upbeat, never complained, and took special delight in talking about her son.

"He's not a fan of hospitals," she told me one day when I went to check in on her. "He never liked going to his doctor's appointments when he was little. Even as a baby. But he's going to stop by today. Any minute now, in fact."

I hoped that her son would show up. She'd been saying for a while now that he would. But this time, she was right. A few moments later, she stopped midsentence, her eyes lighting up as her gaze went over my shoulder.

"Andre!" She exclaimed.

I turned and saw a lanky kid, barely 20, wearing a backward baseball cap, baggy shorts, and an oversized T-shirt with something written in graffiti across the front I could not decipher. A thick gold chain hung around his neck, and the smile he had for his mother rapidly turned into a scowl when I introduced myself.

Sharon beamed as he shuffled in, head bowed, and took a seat by his mother's bed. "Having to deal with my illness has been hard on him."

"No it hasn't," he said with a frown, but his voice betrayed his words. He stared intently at his shoes.

"I'll give you some time alone." I bid Sharon goodbye, then waved to Andre, who continued to ignore me.

The days turned into weeks as Sharon's condition persisted. One morning, I went in to check on her and found Andre sitting in his usual chair, telling her about a movie he had seen last night. He paused when I came into the room, then nodded at me. It was progress.

What's more, Andre had brought over a new vase overflowing with colorful tulips, now sitting on the windowsill.

Sharon had a few magazines on the bed next to her, also courtesy of Andre. Perhaps he was simply getting more at ease here, but this Andre was infinitely more spirited than the one I had first met. I sat by Sharon's bed to listen in, and by the end of his tale about a friend trying to smuggle a double cheeseburger and fries into the movie theater, both Sharon and I were laughing.

Afterward, I went over to Max, an older patient with whom Sharon shared her room. As I checked his vitals, he rattled off a list of complaints.

"I need some water," he said. "I don't know how many times I've asked for water."

Before I could reply, a nurse appeared by the doorway, signaling to me for the start of rounds.

I glanced over and saw Andre sitting in his chair, head cocked toward us, as though he was listening. A sudden thought occurred to me.

"Hey, Andre," I said. "Would you mind grabbing this gentleman some water?" This was not an idea I would have entertained at my university hospital, with its rigid hierarchy and stringent rules on patient confidentiality.

Andre gingerly got up and started rummaging through the cabinet by the sink. He found a plastic cup and a pitcher, which he filled and brought over to Max.

I stopped by an hour later to find Sharon napping and, to my surprise, Andre still speaking with Max. Andre sat by Max's bed as they animatedly discussed their favorite movies. I continued on my way, not wanting to interrupt their conversation.

I ran into Andre later that afternoon and complimented him on helping with Max.

"Uh. . sure, don't mention it," Andre responded, "He kind of reminded me of my dad."

I saw this as an opportunity to push further and suggested he apply for a position as a volunteer.

He cracked a smile but quickly looked down at his shoes. "I don't know about that. Like a hospital worker? I don't think I'm qualified."

"I think you'd be really good at it. You certainly made Max's day."

He nodded slowly, and I thought I saw his mind struggle, as if there was a part of him holding back. 
"Just give it a try," I persisted. "If it turns out it isn't for you, that's okay too."

"I will. . .think about it," he muttered.

I would later reflect on why I had been so determined that day to convince Andre to volunteer. Sure, we were perpetually short-handed. But volunteer recruitment was hardly in my purview, and it wasn't as if Andre had come brimming with enthusiasm to help. Perhaps it was a perception of how much Andre meant to Sharon, tipping me off to the possibility that encouraging Andre to engage in something positive could be, in a way and by extension, helping my patient too, however unconventionally. I was additionally aware of my uniquely persuasive place, what with my position of authority and generational similarity to Andre.

I next saw Andre a couple of weeks later. He was with a new patient, and I almost didn't recognize him, despite the fact that he was still wearing his signature outfit. I wasn't sure if Andre was just the sort of person who seemed closed off until he got comfortable or if it was something more than that. A few moments after he saw me enter the room, he came over, an easy grin on his face.

"So guess what?" he asked, as if resuming a conversation. "I took your advice-I'm going to be a volunteer here. You know, like with an official title. I figure I'm here a lot to see my mom, and I've been chatting with some of the other patients in here. Some seem kinda lonely, actually."

I nodded. "Some don't have many visitors. I think it's great you're going to volunteer."

"I've never done anything like it before, but I actually like being here." He laughed. "I know it's weird to say that about hospitals, but it's true."

Hiding my elation was difficult. The prospect of exerting often-unexpected and fortuitous influences-physically, emotionally, psychologically, socially - not just on patients but also on those near them was what had drawn me to medicine in the first place.
When I next checked in on Carl, he was in a better mood; his wife had been in for a visit, though she had forgotten to bring the lime seltzer. Carl told me Andre had dropped by the store.

"From what my wife says, things at the store are actually going pretty well. So that's good. And then right before she left, that Andre kid stopped in and actually apologized. Which Lena was quite taken by. She's all about forgiving anyone who wants to say their sorrys. She actually remembered him, too." He laughed. "But she was much more welcoming to him than I was."

"I think that's great." I briefly wondered what the likelihood of something like this happening at a larger hospital would be.

There was a knock, and Andre appeared. He had a bottle of cold lime seltzer. "Look what I got for you!"

Carl grinned. "Now that's what I'm talking about." His grin widened as he looked at me. "Can you believe this? All it took was me getting a serious illness to get this kid to finally repay me!”

It could have been an awkward moment. The mood could have soured. But it did not-instead, Carl twisted open the bottle of seltzer and toasted Andre. And I stood there and watched, slightly in wonder, the two of them smiling and bantering with each other.

However amiably I had initially approached Andre, I couldn't deny that a sliver of me had at the outset judged him coarse and unsociable, hardly the qualities of a hospital volunteer. And I had at first found Carl cantankerous and needlessly unforgiving. Yet my initial presumption of the unlikeliness of their reconciliation, juxtaposed with the scene now unfolding before me, has only since cautioned me against making assumptions about my patients and encouraged me to broaden my understanding of what helping them can mean, even in the most unexpected of ways.

To see this article online, please go to: http://jabfm.org/content/33/ 3/481.full. 